\title{
Reproductive output traits of the simultaneous hermaphrodite Serranus scriba in the western Mediterranean
}

\author{
JOSEP ALÓS ${ }^{1}$, ALEXANDRE ALONSO-FERNÁNDEZ² ${ }^{2}$ IGNACIO A. CATALÁN ${ }^{1}$, \\ MIQUEL PALMER ${ }^{1}$ and SUSAN LOWERRE-BARBIERI ${ }^{3}$ \\ ${ }^{1}$ Instituto Mediterráneo de Estudios Avanzados (IMEDEA), CSIC-UIB, C/ Miquel Marqués 21, 07190, Esporles, \\ Illes Balears, Spain. \\ ${ }^{2}$ Instituto de Investigaciones Marinas (IIM), CSIC, C/ Eduardo Cabello 6, 36208, Vigo, Pontevedra, Spain. \\ E-mail: alex@iim.csic.es \\ ${ }^{3}$ Florida Fish and Wildlife Conservation Commission, Fish and Wildlife Research Institute, St. Petersburg, Florida, USA.
}

\begin{abstract}
SUMMARY: We studied multiple individual parameters that affect the reproductive output in the painted comber Serranus scriba, a simultaneous hermaphroditic fish that is widely exploited by recreational fishing in temperate marine coastal regions. Batch fecundity was significantly affected by maternal size, but was not related to maternal age or condition. However, egg quality as estimated by egg dry weight was significantly influenced by the interaction effect of maternal size and age. An empirical assessment demonstrated the existence of a diel spawning pattern based on a daily release of a partial fraction of eggs related to sunset time. Buoyancy varied during the incubation period, but it consistently resulted in positive buoyancy that situated the eggs near the top of the water column. This study represents the first estimation of reproductive output of the simultaneous hermaphrodites $S$. scriba and also provides a comprehensive study about the potential maternal factors that affect egg production. These results are a crucial step towards ongoing efforts to improve the stock assessment of this species.
\end{abstract}

Keywords: batch fecundity, egg buoyancy, egg quality, maternal effects, Mediterranean, Serranus scriba.

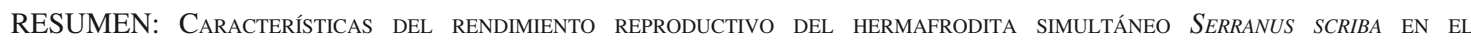
MediterRáneo Occidental (Islas Baleares). - Se estudiaron varios parámetros individuales que afectan el éxito reproductivo de la especie Serranus scriba, un pez hermafrodita simultáneo que es intensamente explotado por la pesca recreativa en regiones costeras de aguas templadas. La fecundidad parcial está significativamente relacionada con el tamaño de los individuos; pero no se encontró relación con la edad o condición. Sin embargo, la calidad de los huevos (estimada a partir del peso seco) resultó significativamente influenciada por la interacción del tamaño y edad de los individuos. Se demostró empíricamente la existencia de un patrón de desove diario, basado en la puesta diaria de una fracción de los huevos del total con anterioridad a la puesta del sol. La flotabilidad de los huevos varió durante el período de incubación; pero presentando de forma consistente una flotabilidad positiva que sitúa a los huevos liberados cerca de la parte más superficial de la columna de agua. Este estudio representa la primera estimación de los parámetros reproductivos relacionados con la producción de huevos en el hermafrodita simultáneo Serranus scriba. Proporciona además un detallado estudio sobre los posibles factores parentales que afectan a la producción de huevos en esta especie. Estos resultados son un paso fundamental para los esfuerzos en curso para mejorar la evaluación y gestión de las poblaciones de Serranus scriba.

Palabras clave: fecundidad parcial, flotabilidad de los huevos, calidad del huevo, efectos parentales, Mediterráneo, Serranus scriba.

\section{INTRODUCTION}

Stock-recruitment (SR) models are used to represent the fundamental relationship between the parent population and the number of offspring produced and are an important tool for the management of harvested populations (Ricker 1975, Needle 2001). However, traditional SR relationships that use spawning stock bio- 
mass (SSB) to represent reproductive potential assume that female SSB is proportional to fecundity and that the proportionality remains constant over time, which can lead to overly optimistic assessments of stock status (Marshall et al. 2006). There is increasing awareness that these assumptions are invalid and that the capacity of a population to produce viable eggs and larvae each year is extremely important for fisheries sustainability and stock recovery (Marshall et al. 1998). Alternative indicators of stock health have been increasingly suggested on the basis of the Trippel (1999) definition of stock reproductive potential.

One main component of variation in stock reproductive potential is total egg production. The total egg production of a stock may vary because of changes in reproductive output with size or age, and thus provides a better understanding of observed fluctuations in reproductive output than SSB, enhancing our ability to estimate recruitment and population growth rates (Lambert 2008). However, the reproductive potential of a population does not refer only to the total egg production of the stock but also to egg and larval viability (Trippel 1999). In this respect, the term "egg quality" may refer either to the ability of a female to produce viable offspring (Nissling et al. 1998) or to the egg's potential to produce viable fry (Kjorsvik et al. 1990). Egg size is the most reported of egg quality features in marine wild populations, and may be quantified by either egg diameter or dry mass. Buoyancy, defined as the ability of these pelagic early life stages to float in sea water, is often used as a positive criterion of quality (Brooks et al. 1997) affecting reproductive success (Vallin and Nissling 2000, Saborido-Rey et al. 2003). Buoyancy is also as a key variable in drift models, so the position of the egg in the water column and associated changes throughout development are fundamental issues in assessing egg viability and the effects of specific environmental scenarios on egg dispersal (e.g. Coombs et al. 1985, 1990, Adlandsvik et al. 2001). Spawning events typically occur at the diel time scale, and these affect reproductive success through the probability of fertilization, rates of predation, and dispersion of eggs and larvae (Lowerre-Barbieri et al. 2011).
In most cases, the empirical data regarding these traits are missing or very scarce, particularly when the stocks are exploited by non-commercial recreational fisheries.

The painted comber, Serranus scriba (Linnaeus, 1758), is a serranid species inhabiting temperate littoral areas. This species is a main contributor to the total fish biomass in seagrass meadows, where it typically lives (Deudero et al. 2008). It is considered a by-catch or low-value species by the commercial fishery, but it is highly targeted and appreciated by the recreational fishery (Morales-Nin et al. 2005, Alós et al. 2008). S. scriba is a simultaneous hermaphrodite, with asynchronous oocyte development and a batch spawning pattern (Tuset et al. 2005, Zorica et al. 2005, AlonsoFernández et al. 2011). Sexual maturity is achieved during the first or second year (Alos et al. 2010), and the spawning season extends from May to August, with a peak of spawning activity between May and June in the western Mediterranean (Alonso-Fernández et al. 2011). However, the reproductive timing and egg production traits (fecundity and egg quality), as well as the individual variability of factors affecting these reproductive parameters, remain unknown. Therefore, the objectives of this study were i) to evaluate the individual reproductive output (quantity and quality) and the maternal factors (size, age and condition) that might impact these reproductive traits; ii) to study timing and frequency of spawning events at a diel temporal scale; and iii) to determine the buoyancy of eggs as they undergo embryonic development.

\section{MATERIALS AND METHODS}

\section{Estimating batch fecundity and egg dry weight and testing influence of maternal factors \\ (Objective No. 1)}

Sampling for this objective was conducted on 29 May 2006 (Table 1) during the peak of the spawning season (Alonso-Fernández et al. 2011). Two locations in Palma Bay (Balearic Islands, NW Mediterranean) were sampled using an experimental beam trawl (Deudero et al. 2008). The two locations had similar

TABLE 1. - Serranus scriba. Summary of main fish features (mean \pm sd) from sampling surveys for each of the objectives presented in the present study.

\begin{tabular}{lccccc}
\hline Objective No. 1 & $\mathrm{n}$ & Total length & Age & RC & HSI \\
\hline Location A & 27 & $126.4 \pm 22.9$ & $3.4 \pm 1.5$ & $1.02 \pm 0.05$ & $1.47 \pm 0.85$ \\
Location B & 19 & $107.5 \pm 20.8$ & $2.8 \pm 2.1$ & $1.03 \pm 0.03$ & $1.57 \pm 0.34$ \\
Total & 46 & $118.6 \pm 23.8$ & $3.1 \pm 1.7$ & Age & GSI \\
\hline Objective No. 2 & $\mathrm{n}$ & Total length & $1.03 \pm 0.04$ & $2.46 \pm 0.75$ \\
\hline Before sunset & 14 & $151.1 \pm 11.9$ & $4.6 \pm 0.6$ & $1.96 \pm 0.58$ \\
Sunset & 19 & $131.3 \pm 19.2$ & $3.1 \pm 1.5$ & $1.97 \pm 0.51$ \\
After sunset & 10 & $146.6 \pm 21.5$ & $3.6 \pm 1.7$ & $2.12 \pm 0.66$ \\
Total & 43 & $141.3 \pm 19.6$ & $3.7 \pm 1.5$ & & \\
\hline Objective No. 3 & $\mathrm{n}$ & Total length & & & \\
\hline Buoyancy & 6 & $145.0 \pm 15.0$ & & \\
\hline
\end{tabular}




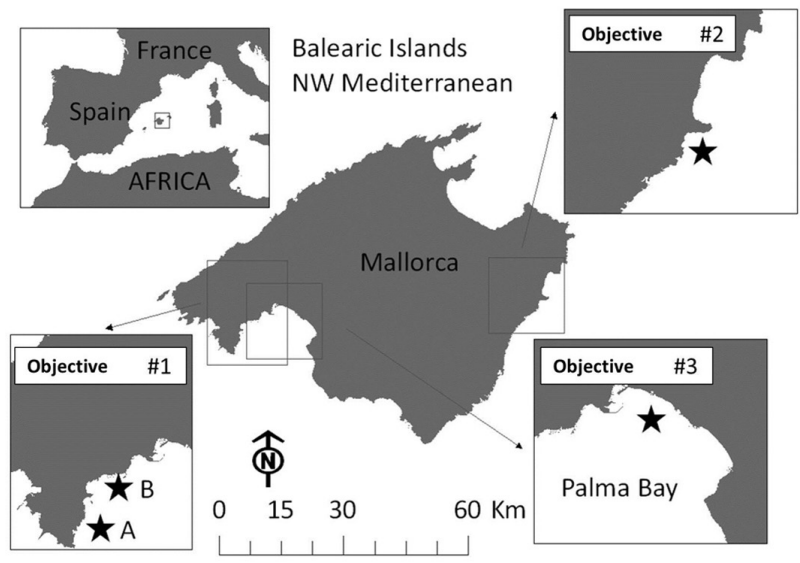

FIG. 1. - Map showing the spatial location (black stars) of the three sampling locations carried out in the waters of the Mallorca Island (NW Mediterranean). For Objective No. 1, the two sampling locations $(\mathrm{A}$ and $\mathrm{B})$ are noted.

habitats, which were characterized by Posidonia oceanica seagrass beds at depths of approximately $20 \mathrm{~m}$ (Fig. 1).

Selection of samples for batch fecundity and egg dry weight analysis was based on gonad histological examination. Thus, gonads were extracted, weighed to the nearest $\mathrm{mg}$ and stored in $10 \%$ buffered formalin for histological processing and fecundity/egg dry weight estimation. The central portion of a fixed gonad was extracted, dehydrated, embedded in paraffin, sectioned to $3 \mu \mathrm{m}$ and stained with haematoxylin (Alonso-Fernández et al. 2011). Batch fecundity (the number of eggs spawned per batch) was estimated for all of the individuals with hydrated oocytes and no newly collapsed post-ovulatory follicles, which indicate recent spawning (Lowerre-Barbieri et al. 2011). Post-ovulatory follicles (POFs) were categorized as follows: 1) newly collapsed POFs (ncPOFs) with an irregular and two-layered convoluted shape, with the follicle cells aligned and a clearly visible lumen; and 2) old POFs (oPOFs) that showed signs of degeneration, with the cell structure of the granulosa cells becoming irregular and the lumen decreasing in size or missing (Fig. 2). We used the gravimetric method in which fecundity is determined as the product of gonad weight and number of hydrated oocytes per gram of ovarian tissue (Murua et al. 2003). An ovarian subsample of approximately $150 \mathrm{mg}$ (around 15\% of the gonad weight) was used to determine batch fecundity. The hydrated oocytes were separated from the ovary manually and counted using a semiautomatic image analysis protocol (Alonso-Fernández et al. 2008). The dry weight (mg/egg) of the hydrated oocytes was used as an indicator of egg quality (Kjørsvik 1994, Brooks et al. 1997). The same gonad subsample from batch fecundity estimates was also used to determine the dry weight of the eggs. Dry weight was determined after drying for $24 \mathrm{~h}$ at $110^{\circ} \mathrm{C}$. The estimation of the mean dry weight of a single hydrated oocyte was obtained by dividing the dry weight of the subsample by the number of hydrated oocytes per subsample.

The following potential maternal factors were sampled. Fish were processed fresh and measured for total length (to the nearest $\mathrm{mm}$ ) and gutted weight and liver (to the nearest $\mathrm{mg}$ ), and their sagittal otoliths were removed. An image of each left otolith was captured using a video camera (LEICAC M165C and Allied vision technologies $($ Marlin F080B) for age estimation. Alternating opaque and translucent bands typically radiate outwards from the nucleus (i.e. the growth centre of the otolith). The width of one opaque band and one translucent band was measured as one annual increment. Annual interpretation of these growth marks has been validated, and the method has been successfully used to age $S$. scriba (Alós et al. 2010). The relative condition of the fish (RC) was used instead of Fulton's condition factor, $\mathrm{K}$, because the latter may be biased by body length (Morgan 2004). The RC was calculated as the ratio between the eviscerated weight and the predicted eviscerated weight from the length/weight relationship of all of the individuals $\left(\mathrm{N}=47, \mathrm{r}^{2}=0.99\right)$. Hepatosomatic index and gonadosomatic index were

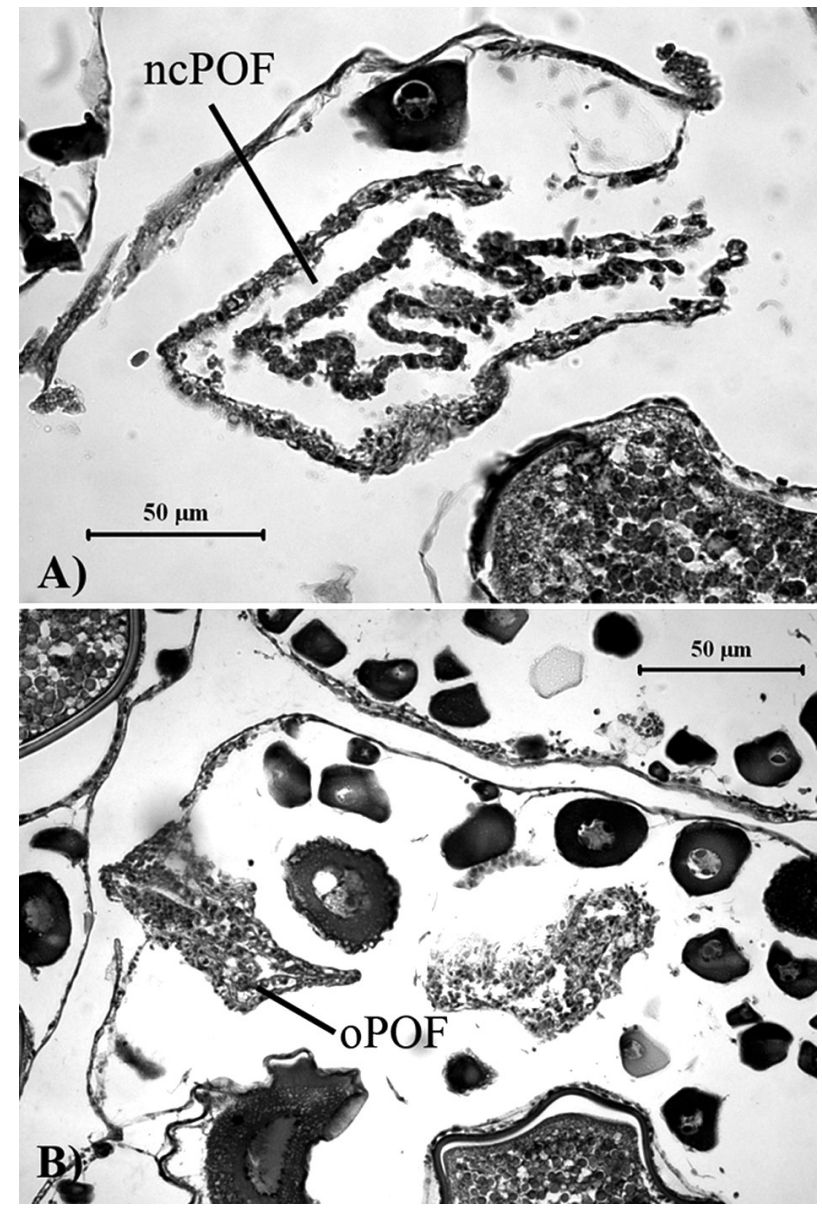

FIG. 2. - Serranus scriba. Classification of post-ovulatory follicles (POFs) used in the present study: newly collapsed POFs (ncPOFs) (A) and old POFs (oPOFs) (B). 
estimated as follows: HSI $=100 *$ (liver weight/gutted weight) and GSI $=100 *$ (gonad weight/gutted weight) and used as proxies of liver energy reserves and gonad development, respectively

We used a mixed model approach (Zuur et al. 2009, Pinheiro et al. 2010) to evaluate effects of maternal factors (total length, age and condition) on egg production (batch fecundity and egg dry weight), including sampling location as a random variable. To meet the assumptions of linearity, batch fecundity and total length were log transformed. Stepwise forward selection was used to select the minimal model according to ANOVA model comparison (Zuur et al. 2007). All the statistical analyses were conducted in R software ( R Development Core Team 2011).

\section{Timing and frequency of spawning (Objective No. 2)}

S. scriba individuals were sampled on June 16th 2011 (Table 1). The samples were collected with the previously mentioned beam trawl fishing method at a coastal site to the east of Mallorca Island (NW Mediterranean, Fig. 1). Three different fishing hauls were conducted, before, during and after sunset at one-hour intervals.

Biological data were collected as described above. Histological indicators of spawning differ in their duration times, affecting how they can be used in reproductive analyses. Ovulation and ncPOFs are extremely short-lived histological indicators and were used as the most conservative way to assess spawning time and location. Therefore, to identify spawning activity and proximity to the time of spawning, ovaries were assessed for presence/absence of the following indicators: oocytes undergoing germinal vesicle migration or hydration indicating imminent spawning, and ncPOFs, indicating very recent spawning (LowerreBarbieri et al. 2009). Old POFs were assumed to be from spawning events on previous days. Differences in spawning activity and proximity to spawning time were explored by assessing the proportion of ovaries with the indicators among sampling periods (before, during and after sunset). Finally, to test the differences in spawning activity between sampling periods (before, during and after sunset) statistically, we used a generalized linear model (family binomial) with presence/absence of hydrated follicles as response variable.

\section{Egg buoyancy through embryonic development (Objective No. 3)}

Six adult $S$. scriba individuals of similar sizes (Table 1) were captured on June 2010 in Palma Bay (Fig. 1) using conventional hook-and-line recreational fishing gear at depths $<20 \mathrm{~m}$ and surface water temperatures of approximately $22^{\circ} \mathrm{C}$. Individuals were caught early in the morning and transported live in tanks for approximately $30 \mathrm{~min}$ to aquaculture facilities
(LIMIA, Government of the Balearic Islands). The fish were measured, weighed and placed in a 400-L polyvinyl chloride tank mounted with flow-through UVsterilized seawater. The temperature and salinity of the system was controlled and monitored continuously.

Spawning was induced through administration of synthetic agonists of gonadotropin-releasing hormone (GnRHa), which has been successfully used in other species of the Serranidae family such as Ephinephelus marginatus (Marino et al. 2003). GnRHa stimulates the pituitary synthesis and release of Luteinizing hormone (LH) and induces ovarian steroidogenesis and follicle maturation (Mylonas and Zohar 2000).

Individuals were slightly anesthetized with MS222, and a dose of GnRHa (hereinafter all values expressed as mean \pm sd, $0.0018 \pm 0.0009 \mathrm{ml}$ per $\mathrm{g}$ of fish) was inserted in the peritoneal cavity using a hypodermic needle. The fish were allowed to spawn undisturbed in the tank, which was examined for the presence of fertilized eggs (eggs floating in an intermediate position) every hour. Adults were removed from the holding tank, and the water flow and aeration was reduced to prevent damage to the eggs. The temperature and salinity remained constant throughout the experiment $\left(\mathrm{T}=22 \pm 0.2^{\circ} \mathrm{C}\right.$, salinity $\left.=37.25 \pm 0.150\right)$.

A sample of approximately 10 eggs was collected every three hours until hatching to estimate changes in buoyancy through development. Egg buoyancy (specific gravity) was measured using the density-gradient column method (Coombs 1981). We used a 1-m column of water with a stable, constant gradient of seawater salt. Glass spheres of a known density were used to calibrate the system (Coombs et al. 1985, 1990). Fertilized, live eggs were introduced at the top of the column and allowed to settle to the location where the egg was in hydrostatic equilibrium with the surrounding fluid. A temperature-controlled water jacket maintained the apparatus at a stable temperature similar to that measured at the time of capture. To select a stable density measurement, we recorded the changes in egg density at increasing observational time points $(10,30$, and $60 \mathrm{~min}$ ). The position of the glass spheres in the density column $(\mathrm{cm})$ was recorded at each observational time point and converted to a temperature-corrected specific gravity $\left(\mathrm{g} \mathrm{cm}^{-3}\right)$ (Coombs 1981). The sinking or ascending velocity $(w)$ at each measured time point was calculated using Stokes' law:

$$
w=\frac{g d^{2} \Delta \rho}{18 v}
$$

where $g$ is the gravitational force, $d$ is the diameter of the egg, $\Delta \rho$ is the difference between the density of the environment and the density of the egg and $v$ is the molecular viscosity (Sundby 1997). We were confident that the properties of the egg remained in agreement with Stokes' law because the diameter of the egg and differences in density yielded Reynolds numbers $<0.5$ (see Sundby 1997). 
TABLE 2. - Serranus scriba. Summary of parameters of the mixed model performed to test the relationship of maternal factors (length and age) with batch fecundity (No. of eggs) and egg dry weight (mg/egg).

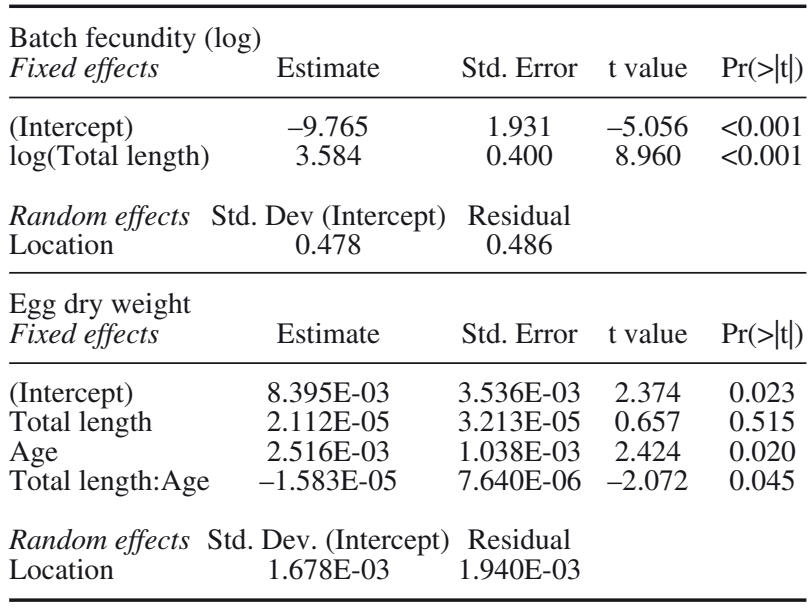

\section{RESULTS}

\section{Estimating batch fecundity, egg dry weight and testing influence of maternal factors} (Objective No. 1)

Batch fecundity increased significantly with total length, but there was no significant effect of age or condition (Table 2, Fig. 3). Egg dry weight was sig-

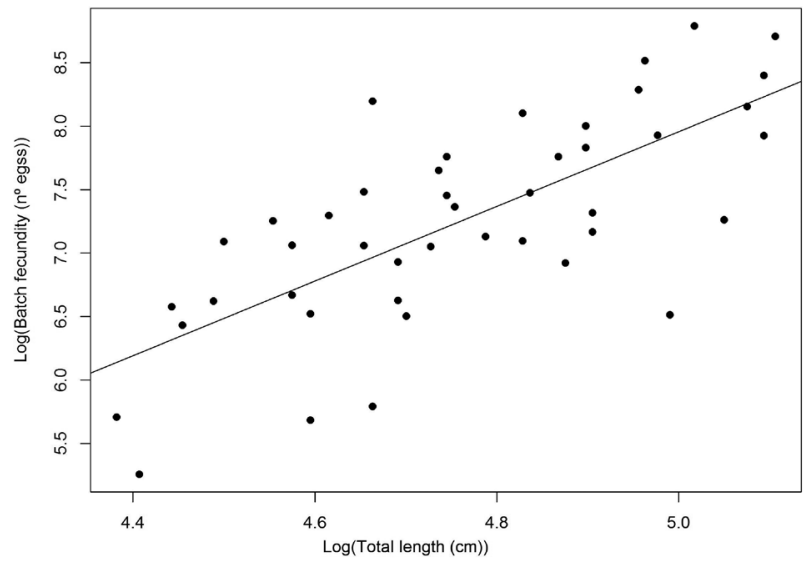

FIG. 3. - Serranus scriba. Fish total length-batch fecundity relationship. Variables were log transformed. Estimated parameters of the relationship are presented in Table 2.

nificantly affected by the interaction of total length and age (Table 2). The positive effect of fish size was more evident in young fish, becoming less important as fish grew (Fig. 4). Influences of condition indices were not considered in any of the final models.

Summarizing, mean batch fecundity was $1913 \pm 1510$ hydrated follicles in $119 \pm 24 \mathrm{~cm}$ total length individuals, and the relative batch fecundity (batch fecundity/g body weight) was $83 \pm 43$ hydrated follicles/g of fish. The corresponding egg dry weight was $0.0125 \pm 0.0023 \mathrm{mg} / \mathrm{egg}$ for the range size of individuals indicated above.
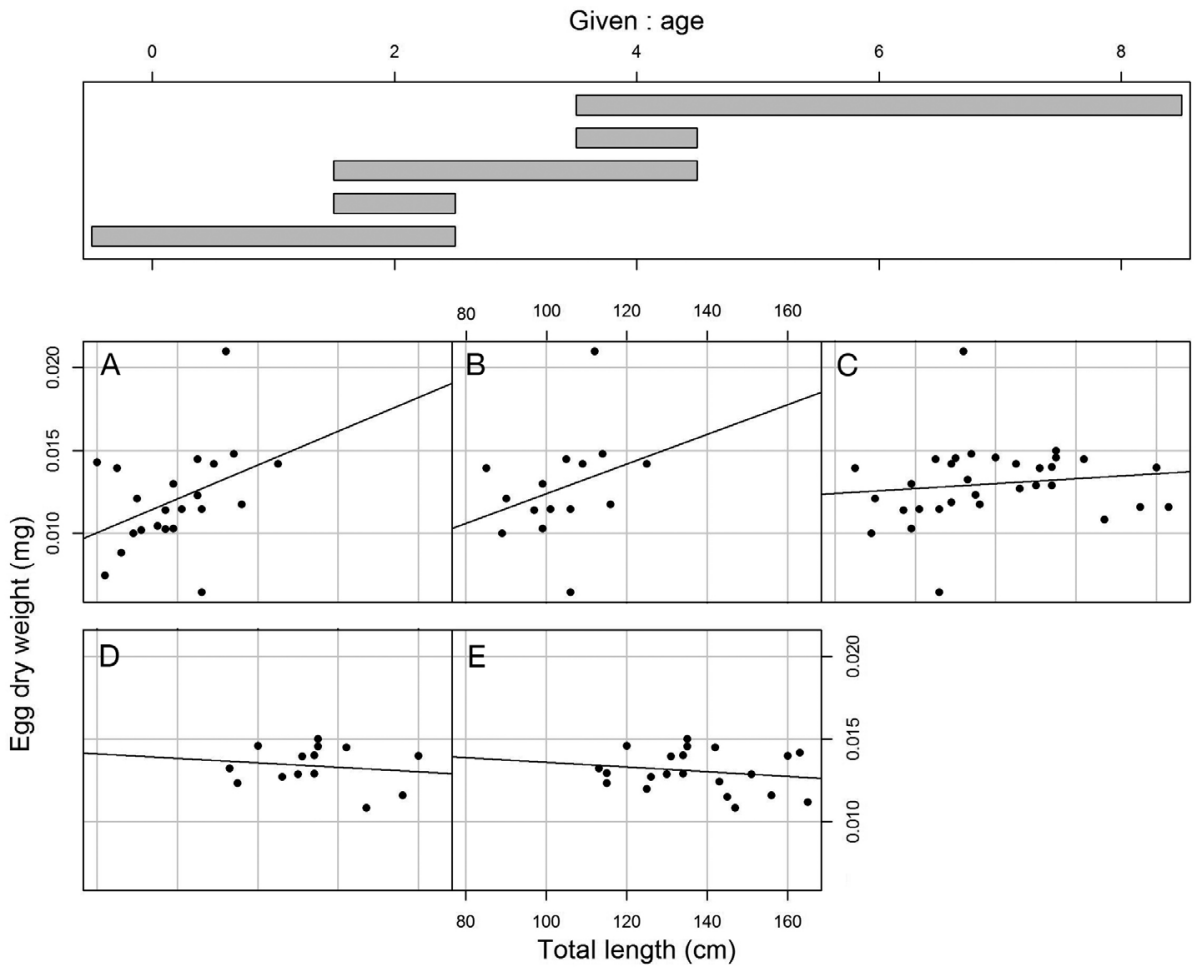

FIG. 4. - Serranus scriba. Coplot for the egg dry weight data in relation to fish total length (x axis) and age (grey bars). Panels show scatterplot between total length and egg dry weight in 0-2 year old fish (A), 2 year old fish (B), 2-4 year old fish (C), 4 year old fish (D) and 4-8 year fish (E). On each panel, a bivariate linear regression model was fitted to aid visual interpretation. Estimate parameters of the relationship (pool data) are presented in Table 2 . 


\section{Timing and frequency of spawning \\ (Objective No. 2)}

A decreasing trend in spawning activity during the sampling periods was evident (Fig. 5A). The percentage of individuals with hydrated oocytes clearly declined during and after sunset and this trend was significant (n="43", Deviance explained $=39 \%$, p-value $<0.0001$ ). In contrast, ncPOF, indicating fish that had recently ovulated, followed the opposite pattern, with a sharp increase in prevalence occurring just after sunset. All fish had histological indicators of spawning activity in the ovary tissue and $90.5 \%$ of the individuals also had a batch of follicles undergoing germinal vesicle migration in preparation for the following night's spawn. However, only a few individuals had oPOFs from the previous day's spawn (Fig. 5B).

\section{Egg buoyancy through embryonic development (Objective No. 3)}

Induced spawning occurred between 21:00 and 21:30 on the first night after the morning of hormone
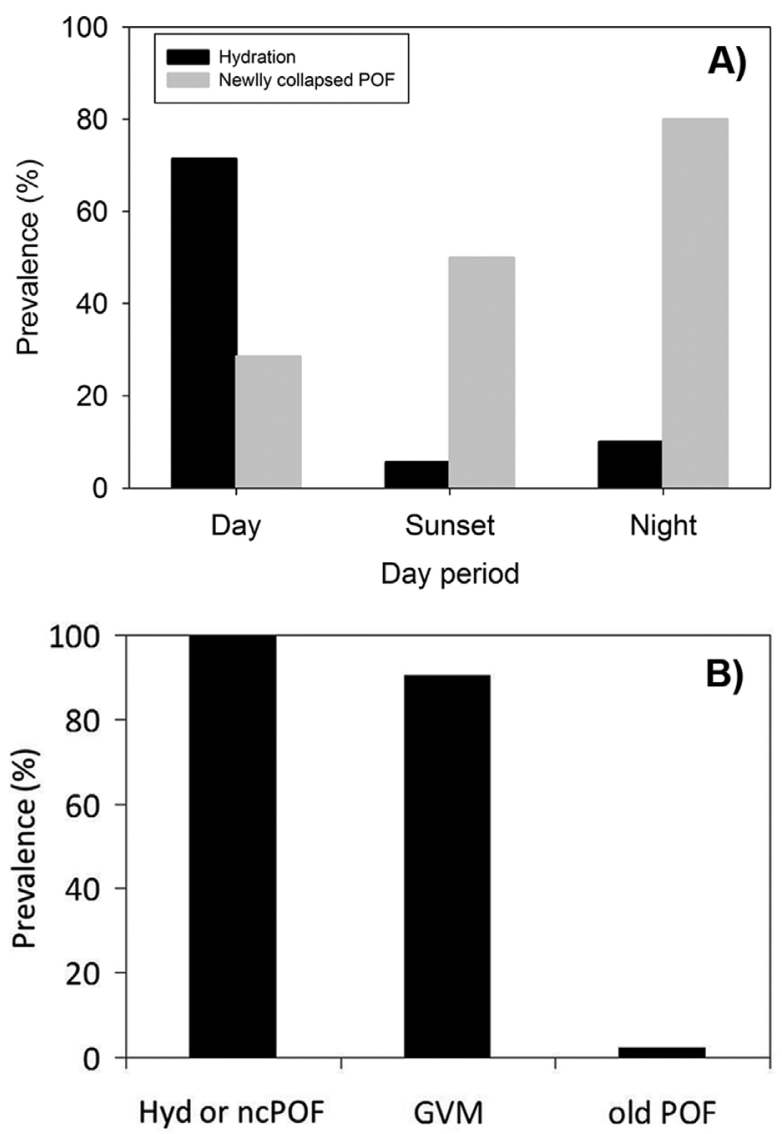

FIG. 5. - Serranus scriba. A, frequency plot showing the percentage of individuals with hydrated oocytes and presence of newly collapsed $\mathrm{POF}$ (ncPOF) related to sampling time (before, during and after sunset). B, frequency plot showing the percentage of individuals with different spawning indicators: hydrated eggs (HYD) or newly collapsed POF (ncPOF), with follicles in germinal vesicle migration (GVM) and old POF pooling all samples from Objective No. 2.

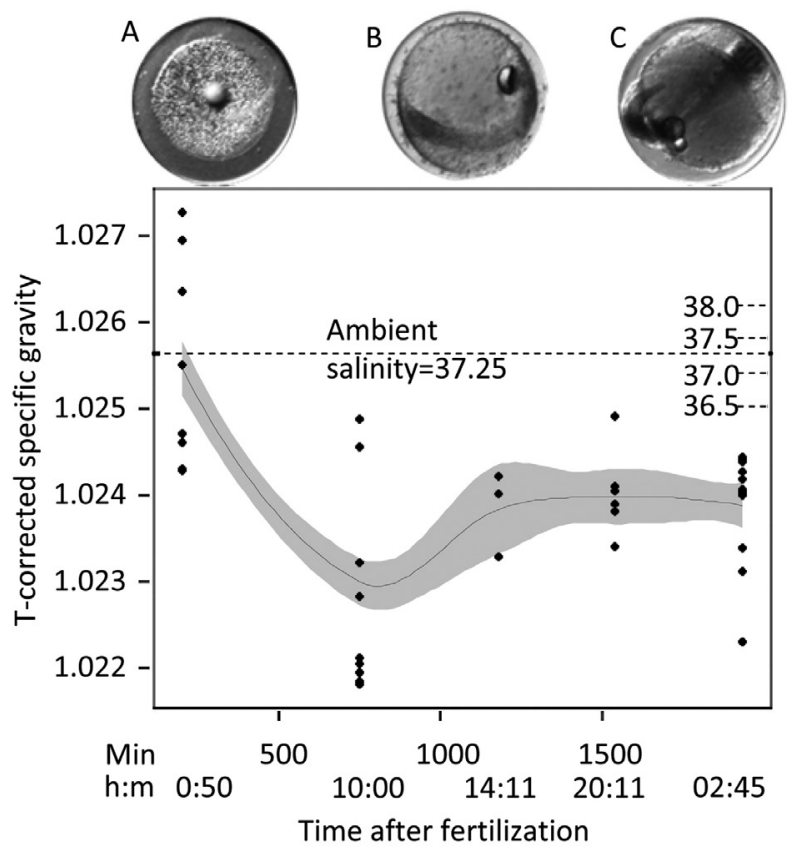

FIG. 6. - Serranus scriba. Specific gravity $\left(\mathrm{g} \mathrm{cm}^{-3}\right)$ of eggs through embryonic development at $22^{\circ} \mathrm{C}$ water temperature. A local smoother (95\% CI, in grey) has been added to aid in the visualization. Dashed line depicts the specific gravity of the local seawater at the culture temperature. The figure also shows three images of egg development at the seven stages of morula (A, 100 min after fertilization), early (B, $897 \mathrm{~min}$ ) and late embryo (C, 1,845 min).

treatment and all eggs hatched by $32.5 \mathrm{~h}$ after fertilization (Fig. 6). Mean diameter of eggs was $799 \pm 32.7 \mu \mathrm{m}$ $(\mathrm{n}=90)$ and eggs had a single oil globule and a relatively small perivitelline space (Fig. 6). Mean specific gravity of the eggs at $50 \mathrm{~min}$ after fertilization resulted in neutral buoyancy. However, for the remainder of the experiment eggs were positively buoyant. At $200 \mathrm{~min}$ after fertilization, the average egg density was again close to neutral buoyancy $\left(5.47 \times 10^{-4} \mathrm{~g} \mathrm{~cm}^{-3}\right)$. However, some eggs undergoing the gastrula stage became heavier at the ambient temperature (Fig. 6). The average excess positive buoyancy at the end of the experiment was $2.07 \times 10^{-3} \mathrm{~g} \mathrm{~cm}^{-3}$, which corresponds to an average ascent velocity of $4.19 \mathrm{~m} \mathrm{~h}^{-1}$ under homogeneous experimental conditions

\section{DISCUSSION}

Recreational fishing constitutes an important use of coastal fisheries resources in the Mediterranean. In the Balearic Islands, a paradigmatic case-study where much research on this issue has been conducted, nearly $10 \%$ of the population actively participates in recreational angling (Morales-Nin et al. 2005). In this archipelago, S. scriba is one of the primary target species of recreational fishing (Morales-Nin et al. 2005) and has been recently reported to be vulnerable to the impact of some recreational angling activities (Alós 2008). 
Morgan (2008) demonstrated that fecundity data can be incorporated into indices of reproductive potential, which can have a great impact on estimates of reference points and recognition of stock status. Furthermore, Lambert (2008) has emphasized the importance of adding measures of fecundity to other parameters for exploited marine fish stocks, in order to improve assessment of reproductive potential. In this context, this is the first study that presents batch fecundity-size relationships for S. scriba total egg production estimations. Fish fecundity data are rarely available in most marine fishery data sets (Tomkiewicz et al. 2003) and $S$. scriba is not an exception, so no previous data are available for comparative purposes. However, our estimations of batch fecundity are considerably lower than for other related species. For example, Serranus atricauda varied between 21774 and 369578 eggs in fish ranging from 22.2 to $39.8 \mathrm{~cm}$ total length (GarcíaDíaz et al. 2006), quite far from our estimations. Wootton (1990) suggests that in general batch fecundity and length are well-related; however, batch fecundity in $S$. scriba showed a poor, although significant, relationship with body size. High spawning frequency in the reproductive season (Alonso-Fernández et al. 2011) makes it possible to find different cohorts of POFs in the same ovary, hampering the identification of individuals with hydrated oocytes that have not yet spawned. This fact can lead to lower estimation of batch fecundity and consequently increasing variance in batch fecundity relationships. In spite of notable advances in methods reducing uncertainty for determining fecundity (Witthames et al. 2009), a number of studies have been conducted to predict fecundity from factors such as food quantity and quality (Bromley et al. 2000, Kraus et al. 2000). Several condition indices have also been used to improve potential fecundity predictions and reproductive success (Kjesbu et al. 1991, Blanchard et al. 2003, Alonso-Fernández et al. 2009). In the present study, the effect of nutritional status on egg production was investigated by using different indices of condition, HSI and RC. However, the condition effect on batch fecundity was not detected in S. scriba, as has been observed in other species, such as the yellow sea bream Dentex hypselosoums (Yoda and Yoneda 2009). If nutritional status is only appreciable at extreme values, manipulative experiments that control condition of individuals in order to achieve a suitable range of condition values may help us to better evaluate how nutritional status affects egg production. However, condition may also act on other reproductive aspects, such as length of the spawning season (Wieland et al. 2000).

Estimation of annual fecundity in indeterminate species requires knowledge not only of batch fecundity but also of the number of batches released within a spawning season. The $S$. scriba spawning season lasts approximately 4 months, with a high spawning fraction inferred from the prevalence of hydrated follicles in the ovaries (Alonso-Fernández et al. 2011), as also seen in the present study. These findings indicate daily spawning behaviour, which is characteristic of other simultaneous hermaphrodites (Petersen 1995). However, species from the same genus, such as Serranus atricauda, have lower spawning fractions, around 25\% (García-Díaz et al. 2006). The assessment of the number of batches is directly dependent on spawning fraction estimations (Armstrong and Witthames 2012). Spawning fraction estimations can be biased due to sampling strategies based on fishing methods, leading to an oversampling of actively spawning individuals (Armstrong and Witthames 2012). Some strategies using POF aging have been suggested to correct this bias (Motos 1996), but for S. scriba there are no data on degeneration of POFs. Thus, no reliable tool was available to avoid this possible bias.

The concept of egg quality is of great interest since high-quality eggs are expected to have more chances to produce viable offspring (Kjorsvik et al. 1990, Nissling et al. 1998). In this paper we refer to "egg quality" as "egg size" (expressed as egg dry weight) under the assumption that "bigger is better" (Miller et al. 1988). Maternal factors on egg quality have been widely recognized in temperate fish species (Nissling et al. 1998, Vallin and Nissling 2000, Marteinsdottir and Steinarsson 1998). However, the relationship between egg quality and maternal age may not be as strong in temperate species (Johnston and Leggett 2002). Moreover, most of the positive relationships regarding maternal age and egg quality correspond to species with a long life span (Berkeley et al. 2004). In S. scriba, egg dry weight was significantly influenced by the interaction of fish size and age, but no influence of fish condition was detected. The positive effect of maternal size was greater in younger fish, possibly indicating some kind of relationship of egg quality variation with fish individual growth patterns and growth rates; but this fact has yet to be tested.

Marine fish species vary widely in their reproductive timing but also exhibit universal reproductive traits, which typically operate over different temporal scales: lifetime, annual, seasonal, and diel (LowerreBarbieri et al. 2011). Ovulation occurs at the diel scale and typically indicates spawning as ovulated eggs in most species remain viable for only a short time period (Lowerre-Barbieri et al. 2009). The highest percentage of individuals with indicators that spawning was imminent was observed before sunset. In contrast, most of the individuals sampled during and after sunset did not show signs of imminent spawning but rather had histological indicators of very recent spawning activity based on the presence of newly collapsed post-ovulatory follicles. These trends confirmed the sunset-related spawning hypothesis in this species, which has been observed in other marine coastal species (e.g. LowerreBarbieri et al. 2009).

This characteristic diel timing of spawning has direct implications in the dispersal capacity of the eggs when the buoyancy results are considered as is explained below . The buoyancy of the eggs released is 
TABle 3. - Serranus scriba. Summary of specific gravity (buoyancy) of eggs previously reported for several teleost fish (after Govoni and Forward, 2008). The table shows the adult habitat, the fish name, the initial and final or point estimate (PE) specific gravity, the mean of ascent velocity (MAV) in $\mathrm{m} \mathrm{h}^{-1}$ and the reference details.

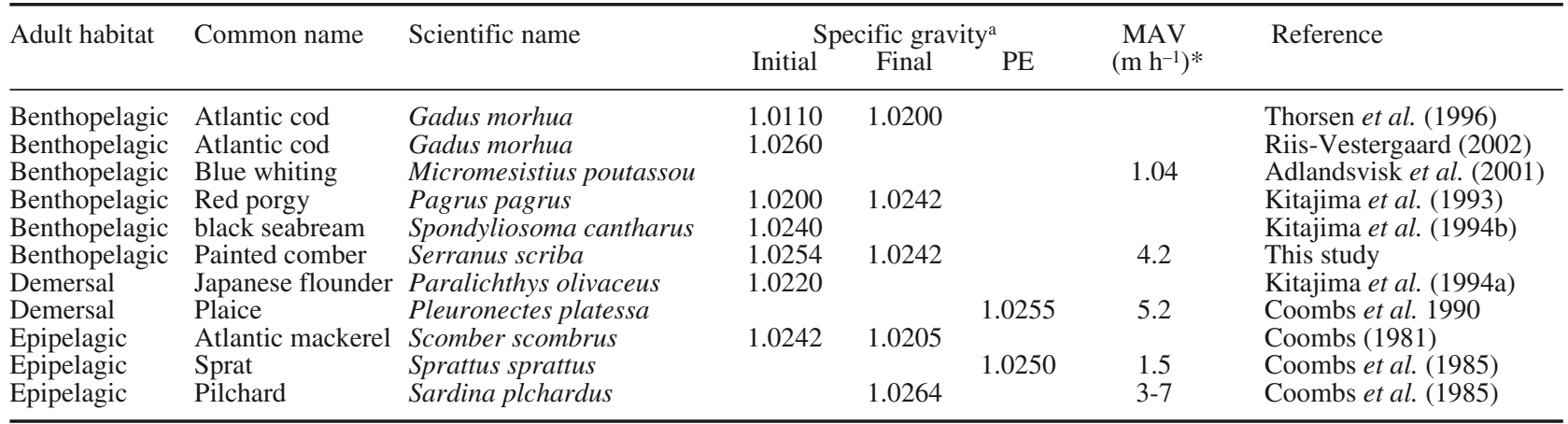

a Initial and final values are temperature-corrected, although for different temperatures for each species

* Except initial or final values

also an important quality measure that is often ignored. Egg buoyancy and changes in buoyancy throughout egg development can have important consequences for dispersal and survival (Ospina-Álvarez et al. 2012). Recently, a numerical simulation of eggs and larval dispersal in the area of study showed that large differences in the probability of remaining in the littoral zone occurred at spatial scales of $20 \mathrm{~km}$ (Basterretxea et al. 2012). Providing new information regarding larval dispersal will help to refine these simulation models. We found positive buoyancy in the eggs released by S. scriba after the first measurement. Several authors have shown a trend towards increased buoyancy with age in pelagic eggs, but several others have obtained opposite results (Govoni and Forward 2008, see Table 3 ). Although it was not possible to increase the measurement frequency for logistic reasons, our results span at least $91 \%$ of the developmental period, so our interpretation of the average egg buoyancy can be considered reliable.

The percentage of perivitelline space of $S$. scriba eggs is small compared with that of other species $(80 \%$ in some clupeiform eggs; Govoni and Forward 2008). Therefore, the potential for osmoregulation in S. scriba is low, implying that the possible underestimation of density is far too small to affect our interpretation (Coombs et al. 1985). Not having a large osmoregulatory potential agrees with the highly stable conditions found during the summer $(P$. oceanica seagrasses only occur in clear waters and are not found close to river plumes).

Diel periodicity or time of spawning will affect reproductive success through the probability of fertilization, rates of predation, and dispersion of eggs and larvae (Yamahira 2001, Cowen et al. 2006, Gladstone 2007). Assuming eggs are at a neutral buoyancy up to 3 hours after being spawned at sunset, it would take the eggs a maximum of $9.5 \mathrm{~h}$ (if spawned at $40 \mathrm{~m}$, the maximum depth for this species) to reach the surface, corresponding to sunrise during the summer period. However, many physical factors may shape the final egg distribution (Sundby 1997), including the spawning behaviour of the adults, wind-induced turbulence and vertical density gradients, which are present in the area during the summer. We admit that without a more precise knowledge of the field data, the interpretation of the consequences of buoyancy remains speculative. However, we believe that the data presented here may be useful for refining existing models of larval dispersion in the area (Basterretxea et al. 2012).

The present study deepens our understanding of reproductive processes of $S$. scriba in the western Mediterranean, which is fundamental for developing future egg production models and estimates of SSB. It supplies new biological information that is useful for improving current egg and larval dispersal models. We also identified three additional areas of research that will complete the current findings: i) a detailed analysis of POF degeneration to improve accuracy in spawning fraction estimations, ii) investigation of influence of maternal factors on timing of reproduction at a different time scale (length of the spawning season), and iii) demographic studies from other localities and seasons in the distribution range to understand the spatio-temporal variation of the reproductive output.

\section{ACKNOWLEDGEMENTS}

This study was partially financed by the research project ARTEVIGO (09MMA022402PR) (Objective No. 1), the research project CONFLICT (CGL200800958) (Objective No. 2) and the research project REC $^{2}$ (CTM2011-23835) (Ojective No. 3) funded by the Spanish Ministry of Science and Innovation. J. Alós was supported by an FPI fellowship (MICINN). We especially thank the numerous researchers involved in the field work, and in particular M. Linde, D. March and M. Cabanellas. We also thank all the personnel of LIMIA for their help in the rearing process.

\section{REFERENCES}

Adlandsvik B., Coombs S., Sundby S., Temple G. 2001. Buoyancy and vertical distribution of eggs and larvae of blue whiting (Micromesistius poutassou): observations and modelling. Fish. Res. 50: 59-72. 
Alonso-Fernández A., Alós J., Grau A., Domínguez-Petit R., Saborido-Rey F. 2011. The use of histological techniques to study the reproductive biology of the hermaphroditic Mediterranean fishes Coris julis, Serranus scriba and Diplodus annularis. Mar Coast Fish. 3: 145-159.

Alonso-Fernández A., Domínguez-Petit R., Bao M., Rivas C., Saborido-Rey F. 2008. Spawning pattern and reproductive strategy of female pouting Trisopterus luscus (Gadidae) on the Galician shelf of north-western Spain. Aquat. Living Resour. 21: 383-393

Alonso-Fernández A., Vallejo A.C., Saborido-Rey F., Murua H., Trippel E.A. 2009. Fecundity estimation of Atlantic cod (Gadus morhua) and haddock (Melanogrammus aeglefinus) of Georges Bank: Application of the autodiametric method. Fish. Res. 99: 47-54.

Alós J. 2008. Influence of anatomical hooking depth, capture depth, and venting on mortality of painted comber (Serranus scriba) released by recreational anglers. ICES J. Mar. Sci. 65: $1620-1625$

Alos J., Palmer M., Balle S., Grau A.M., Morales-Nin B. 2010. Individual growth pattern and variability in Serranus scriba: Bayesian analysis. ICES J. Mar. Sci. 67: 502-512.

Alós J., Palmer M., Grau A.M., Deudero S. 2008. Effects of hook size and barbless hooks on hooking injury, catch per unit effort, and fish size in a mixed-species recreational fishery in the western Mediterranean Sea. ICES J. Mar. Sci. 65: 899-905.

Armstrong M.J., Witthames P.R. 2012. Developments in understanding of fecundity of fish stocks in relation to egg production methods for estimating spawning stock biomass. Fish. Res. 117-118: 35-47.

Basterretxea G., Jordi A., Catalán I.A., Sabatés A. 2012. Modelbased assessment of local-scale fish larval connectivity in a network of marine protected areas. Fish. Oceanogr. 21: 291-306.

Berkeley S.A., Chapman C., Sogard S.M. 2004. Maternal age as a determinant of larval growth and survival in a marine fish, Sebastes melanops. Ecology 85: 1258-1264.

Blanchard J.L., Frank K.Y., Simon J.E. 2003. Effects of condition on fecundity and total egg production of eastern Scotian Shelf haddock (Melanogrammus aeglefinus). Can. J. Fish. Aquat. Sci. 60: 321-322.

Bromley P.J., Ravier C., Witthames P.R. 2000. The influence of feeding regime on sexual maturation, fecundity and atresia in first-time spawning turbot. J. Fish Biol. 56: 264-278.

Brooks S., Tyler C.R., Sumpter J.P. 1997. Egg quality in fish: what makes a good egg? Rev. Fish Biol. Fish. 7: 387-416.

Coombs S.H. 1981. A density-gradient column for determining the specific gravity of fish eggs, with particular reference to eggs of the mackerel Scomber scombrus. Mar. Biol. 63: 101-106.

Coombs S.H., Fosh C.A., Keen M.A. 1985. The Buoyancy and Vertical Distribution of Eggs of Sprat (Sprattus Sprattus) and Pilchard (Sardina pilchardus). J. Mar. Biol. Assoc. UK 65: 461-474

Coombs S.H., Nichols J.H., Fosh C.A. 1990. Plaice eggs (Pleuronectes platessa L.) in the southern North Sea: abundance, spawning area, vertical distribution, and buoyancy. ICES J. Mar. Sci. 47: 133-139.

Cowen R. K., Paris C. B., Srinivasan A. 2006. Scaling of connectivity in marine populations. Science 311: 522-527.

Deudero S., Morey G., Frau A., Moranta J., Moreno I. 2008. Temporal trends of littoral fishes at deep Posidonia oceanica seagrass meadows in a temperate coastal zone. J. Mar. Syst. 70: 182-195.

García-Díaz M., González J.A., Lorente M.J., Tuset V.M. 2006. Spawning season, maturity sizes, and fecundity in blacktail comber (Serranus atricauda) (Serranidae) from the easterncentral Atlantic. Fish. Bull. 104: 159-166.

Gladstone W. 2007. Selection of a spawning aggregation site by Chromis hypsilepis (Pisces: Pomacentridae): habitat structure, transport potential, and food availability. Mar. Ecol. Prog. Ser. 351: 235-247.

Govoni J.J., Forward R.B. 2008. Buoyancy. In: Finn R.N., Kapoor B.G. (eds.), Fish larval physiology. Science Publishers, Enfield, New Hampshire, pp. 495-521.

Johnston T.A., Leggett W.C. 2002. Maternal and environmental gradients in the egg size of an iteroparous fish. Ecology 83: 1777-1791.

Kitajima C., Yamane Y., Matsui S., Kihara Y., Furuichi M. 1993. Ontogenetic change in buoyancy in the early stage of red sea bream. Nippon Suisan Gakkaishi 59: 7.
Kitajima C., Yamane Y., Matsui S. 1994a. Developmental changes in specific gravity in the early stages of the japanese flounder Paralychthys olivacous. Nippon Suisan Gakkaishi 60: 6.

Kitajima C., Yamane Y., Matsui S. 1994b, Ontogenetic changes in specific gravity during early development of black sea bream. Nippon Suisan Gakkaishi 60: 7.

Kjesbu O.S., Klungsoyr J., Kryvi H., Witthames P.R., Greer Walker M. 1991. Fecundity, atresia, and egg size of captive Atlantic cod (Gadus morhua) in relation to proximate body composition. Can. J. Fish. Aquat. Sci. 48: 2333-2343.

Kjorsvik E., Mangor-Jensen A., Holmefjord I. 1990. Egg quality in fishes. Adv. Mar. Biol. 26: 71-114.

Kraus G., Müller A., Trella K., Köuster F.W. 2000. Fecundity of Baltic cod: temporal and spatial variation. J. Fish Biol. 56: 1327-1341.

Lambert Y. 2008. Why Should we closely monitor fecundity in marine fish populations? J. Northwest Atl. Fish. Sci. 41: 93-106.

Lowerre-Barbieri S.K., Ganias K., Saborido-Rey F., Murua H., Hunter J.R. 2011. Reproductive timing in marine fishes: variability, temporal scales and methods. Mar. Coast Fish. 3: 71-91.

Lowerre-Barbieri S.K., Henderson N., Llopiz J., Walters S., Bickford J., Muller R. 2009. Defining a spawning population (spotted seatrout Cynoscion nebulosus) over temporal, spatial, and demographic scales. Mar. Ecol. Prog. Ser. 394: 231-245.

Marino G., Panini E., Longobardi A., Mandich A., Finoia M.G., Zohar Y., Mylonas C.C. 2003. Induction of ovulation in captivereared dusky grouper, Epinephelus marginatus (Lowe, 1834), with a sustained-release GnRHa implant. Aquaculture 219: 841-858.

Marshall C.T., Kjesbu O.S., Yaragina N.A., Solemdal P., Ulltang O. 1998. Is spawner biomass a sensitive measure of the reproductive and recruitment potential of northeast Arctic cod? Can. J. Fish. Aquat. Sci. 55: 1766-1783.

Marshall C.T., Needle C.L., Thorsen A., Kjesbu O.S., Yaragina N.A. 2006. Systematic bias in estimates of reproductive potential of an Atlantic cod (Gadus morhua) stock: implications for stock-recruit theory and management. Can. J. Fish. Aquat. Sci. 63: 980-994.

Marteinsdottir G., Steinarsson A. 1998. Maternal influence on the size and viability of Iceland cod Gadus morhua eggs and larvae. J. Fish Biol. 52: 1241-1258.

Miller T.J., Crowder L.B., Rice J.A., Marschall E.A. 1988. Larval Size and Recruitment Mechanisms in Fishes: Toward a Conceptual Framework. Can. J. Fish. Aquat. Sci. 45: 1657-1670.

Morales-Nin B., Moranta J., Garcia C., Tugores M.P., Grau A.M., Riera F., Cerda M. 2005. The recreational fishery off Majorca Island (western Mediterranean): some implications for coastal resource management. ICES J. Mar. Sci. 62: 727-739.

Morgan M.J. 2004. The relationship between fish condition and the probability of being mature in American plaice (Hippoglossoides platessoides). ICES J. Mar. Sci. 61: 64-70.

Morgan M.J. 2008. Integrating reproductive biology into scientific advice for fisheries management. J. Northwest Atl. Fish. Sci. 41: 37-51

Motos L. 1996. Reproductive biology and fecundity of the Bay of Biscay anchovy population (Engraulis encrasicolus L.). Sci. Mar. 60: 195-207.

Murua H., Kraus G., Saborido-Rey F., Witthames P.R., Thorsen A., Junquera S. 2003. Procedures to estimate fecundity of marine fish species relation to their reproductive strategy. J. Northwest Atl. Fish. Sci. 33: 33-54.

Mylonas C.C., Zohar Y. 2000. Use of GnRHa-delivery systems for the control of reproduction in fish. Rev. Fish Biol. Fish. 10: 463-491.

Needle C.L. 2001. Recruitment models: diagnosis and prognosis. Rev. Fish Biol. Fish. 11: 95-111.

Nissling A., Larsson R., Vallin L., Frohlund K. 1998. Assessment of egg and larval viability in cod, Gadus morhua: methods and results from an experimental study. Fish. Res. 38: 169-186.

Ospina-Álvarez A., Palomera I., Parada C. 2012. Changes in egg buoyancy during development and its effects on the vertical distribution of anchovy eggs. Fish. Res. 117-118: 86-95.

Petersen C. 1995. Reproductive behavior, egg trading, and correlates of male mating success in the simultaneous hermaphrodite, Serranus tabacarius. Environ. Biol. Fishes 43: 351-361.

Pinheiro J., Bates D., DebRoy S., Sarkar D. 2010. nlme: Linear and Nonlinear Mixed Effects Models. R package version 3.1-97 [online]. 
R Development Core Team. 2011. R: A Language and Environment for Statistical Computing. Vienna, Austria, R Foundation for Statistical Computing.

Ricker W. 1975. Computation and interpretation of biological statistics of fish populations. Otawa, Department of environment fishereis and marine service. Bull. Fish. Res. Board of Canada.

Riis-Vestergaard J. 2002. Energy density of marine pelagic fish eggs. J. Fish Biol. 60: 1511-1528.

Saborido-Rey F., Kjesbu O.S., Thorsen A. 2003. Buoyancy of Atlantic cod larvae in relation to developmental stage and maternal influences. J. Plankton Res. 25: 291-307.

Sundby S. 1997. Turbulence and ichthyoplankton: influence on vertical distributions and encounter rates. Sci. Mar. 61: 159-176.

Thorsen A., Kjesbu O. S., Fyhndr H. J., Solemdal P. 1996. Physiological mechanisms of buoyancy in eggs from brackish water cod. J. Fish. Biol. 48: 457-477.

Tomkiewicz J., Morgan M.J., Burnett J., Saborido-Rey F. 2003. Available information for estimating reproductive potential of Northwest Atlantic Groundfish stock. J. Northwest Atl. Fish. Sci. 33: 1-21.

Trippel E.A. 1999. Estimation of stock reproductive potential: history and challenges for Canadian Atlantic gadoid stock assessments. J. Northwest Atl. Fish. Sci. 25: 61-81.

Tuset V.M., Garcia-Diaz M.M., Gonzalez J.A., Lorente M.J., Lozano I.J. 2005. Reproduction and growth of the painted comber Serranus scriba (Serranidae) of the Marine Reserve of Lanzarote Island (Central-Eastern Atlantic). Estuar. Coast. Shelf Sci. 64: 335-346.

Vallin L., Nissling A. 2000. Maternal effects on egg size and egg buoyancy of Baltic cod, Gadus morhua. Implications for stock structure effects on recruitment. Fish. Res. 49: 21-37.
Wieland K., Jarre-Teichmann A., Horbowa K. 2000. Changes in the timing of spawning of Baltic cod: possible causes and implications for recruitment. ICES J. Mar. Sci. 57: 452-464.

Witthames P.R., Thorsen A., Greenwood L.N., Saborido-Rey F., Dominguez R., Murua H., Korta M., Kjesbu O.S. 2009. Advances in methods for determining fecundity: application of the new methods to some marine fishes. Fish. Bull. 107: 148-164.

Wootton R.J. 1990. Ecology of teleost fishes. Dordrecht, The Netherlands, Kluwer Academic Publishers. Fish and Fisheries Series.

Yamahira K. 2001. Experimental examination of interpopulation variation in reproductive timing of a fish. Oecologia 128: 389-399.

Yoda M., Yoneda M. 2009. Assessment of reproductive potential in multiple-spawning fish with indeterminate fecundity: a case study of yellow sea bream Dentex hypselosomus in the East China Sea. J. Fish. Biol. 74: 2338-2354.

Zorica B., Sinovcic G., Cikes Kec V. 2005. Reproductive period and histological analysis of the painted comber, Serranus scriba (Linnaeus, 1758), in the Trogir Bay area (eastern mid-Adriatic). Acta Adriat. 46: 77-82.

Zuur A.F., Ieno E.N., Walker N., Saveliev A.A., Smith G.M. 2009. Mixed effects models and extensions in ecology with $R$. New York, Springer. Statistics for Biology and Health.

Zuur A.F., Leno E.N., Smith G.M. 2007. Analysing ecological data: Statistics for biology and health. New York, Springer.

Scient. ed.: E. Macpherson.

Received October 5, 2012. Accepted February 15, 2013.

Published online March 26, 2013. 